\title{
Improvement of $\mathrm{V}_{2} \mathrm{O}_{5}-\mathrm{WO}_{3} / \mathrm{TiO}_{2}$ Supported Catalytic Sheet Filter for Simultaneous Reduction of $\mathrm{NO}_{\mathrm{x}}$ and Particulates
}

\author{
Phule A. D., Choi J. H., and Kim J. H.
}

\begin{abstract}
Improvement of $\mathrm{V}_{2} \mathrm{O}_{5}-\mathrm{WO}_{3} / \mathrm{TiO}_{2} \quad$ (VWT) supported catalytic sheet filter (SF) has been achieved by using a simple dip coating method with varied concentration of ball milled catalyst coating solution (10-30 wt \%) and discussed their NO conversion performances at different reaction temperature $\left(220-380{ }^{\circ} \mathrm{C}\right)$. Increase in the catalyst concentration more than $15 \mathrm{wt} \%$ it observed the bimodal particle size distribution with the particle size of $\sim 1$ micron and $>2$ micron, which leads to increase in pressure loss of catalyst filter as result to improve the NO conversion performance from $50 \%$ (BM10SF) to more than $90 \%$ (BM25SF and BM30SF) at reaction temperature range of 260-360 ${ }^{\circ} \mathrm{C}$ with $\mathrm{N}_{\mathrm{x}}$ leakage less than $50 \mathrm{ppm}$ in the reaction temperature range of $280-340{ }^{\circ} \mathrm{C}$. Microstructural study with the help of an optical images explained the surface morphology of the SF with empty and buried (with VWT catalyst) pores. The filtration rate was less than $0.01 \mathrm{~m} / \mathrm{s}$, the NO conversion rate of $90 \%$ or more was achieved.
\end{abstract}

Index Terms - Ball milling, dip coating, NOx and particulates reduction, $\mathrm{SCR}$ catalyst, $\mathrm{V}_{2} \mathrm{O}_{5}-\mathrm{WO}_{3} / \mathrm{TiO}_{2}$ catalytic sheet filter.

\section{INTRODUCTION}

Emission of nitrogen oxides in fuel from the stationary sources primarily from power stations, industrial heaters and cogeneration plants, diesel engines represents a major worldwide environmental problem. NOx is blamed for the formation of ozone in troposphere, the production of acid rains, and respiratory problems to mankind [1]. Also the fine dust emission which negatively affects the human body has intended to increase every year in a world. One of the most efficient technologies for the reduction of NOx emission as well as particulates is the selective catalytic reduction (SCR) with $\mathrm{NH} 3$ over catalyst based on $\mathrm{V}_{2} \mathrm{O}_{5}-\mathrm{WO}_{3} / \mathrm{TiO}_{2}$ (VWT) [2], [3]. These catalysts are utilized in the rigid forms supported on the surface of ceramic filter elements in the industrial fields However, plugging of their gas flow path is one of the serious operational problems which leads to the limited-application of SCR catalyst working at the dust-free stream only [4]. In order to overcome the problems pointed above, highly effective catalyst supported in the pores of the ceramic sheet

Manuscript received April 12, 2018; revised June 23, 2018. This work was supported by the funding from the ATC of Korea Evaluation Institute of Industrial Technology (KEIT) grant funded by the Korea government Ministry of Knowledge Economy (No. 10067551)

Phule A. D. and Choi J. H. are with Chemical Engineering Department, Gyeongsang National University, Jinju-52828, South Korea (e-mail: ajitphule_b4u@gnu.ac.kr,jhchoi@gnu.ac.kr).

Kim J. H. is with Kyungsung Industry Co., LTD, Noksansandan 382 Ro 14 Bungil 41, Kangsu Gu, Busan, South Korea (e-mail: hyoungga@nate.com). filter elements is one of the solutions to prevent the plugging problem and to provide a low pressure drop of the system as well as keeping an important advantage owing to the simultaneous treatment of particulates and NOx.

The schematic of SCR process is as showed in Fig. 1 and which is based mainly on the following reactions:

$$
\begin{gathered}
4 \mathrm{NH}_{3}+4 \mathrm{NO}+\mathrm{O}_{2} \rightarrow 4 \mathrm{~N}_{2}+6 \mathrm{H}_{2} \mathrm{O} \\
2 \mathrm{NH}_{3}+\mathrm{NO}+\mathrm{NO}_{2} \rightarrow 2 \mathrm{~N}_{2}+3 \mathrm{H}_{2} \mathrm{O} \\
8 \mathrm{NH}_{3}+6 \mathrm{NO}_{2} \rightarrow 7 \mathrm{~N}_{2}+12 \mathrm{H}_{2} \mathrm{O}
\end{gathered}
$$

Reaction (1) proceeds very rapidly over the catalyst in the temperature range of $250-450{ }^{\circ} \mathrm{C}$ with excess $\mathrm{O}_{2}$ and the accounts of overall stoichiometry of the process $\left(\mathrm{NH}_{3} / \mathrm{NO}=\right.$ 1:1), since NOx typically consists of $>90 \%$ NO. The selective term refers to the ability of ammonia to react selectively with $\mathrm{NOx}$ instead of being oxidized by oxygen to form $\mathrm{N}_{2}, \mathrm{~N}_{2} \mathrm{O}$, and $\mathrm{NO}$; this ability has not been observed in the case of other simple reagents such as carbon monoxide and hydrocarbons and is thus unique of ammonia [1].

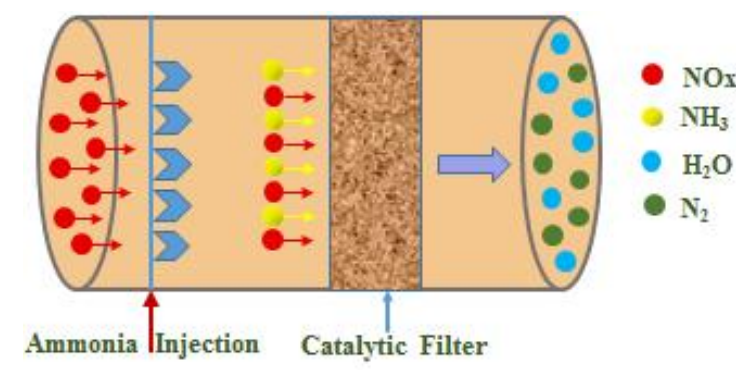

Fig. 1. Schematic of the selective catalytic reduction system.

In our study, we are using the simple solution (which has been prepared by using ball milling process to receive the catalyst particles with particular size distributions) dip coating technique to fabricate the $\mathrm{V}_{2} \mathrm{O}_{5}-\mathrm{WO}_{3} / \mathrm{TiO}_{2}$-supported ceramic catalytic sheet filters for simultaneous reduction of NOx and particulates with $\mathrm{NH}_{3}$. We observed the effect of coating solution concentration on NOx reduction performance of the prepared VWT supported ceramic catalytic sheet filter. Particle size distribution of catalyst has been analyzed by using the ball milled coating solution. As the reaction time is a very important factor for completion of the reaction which performs at the surface of the catalytic filters, we studied the effect of face velocity on the NOx reduction reaction. Microstructure of the coated and virgin 
sheet filters has been characterized by optical microscope to make sure that the pores of the ceramic sheet filters has been buried/filled with the VWT catalyst.

\section{EXPERIMENTAL}

\section{A. Preparation of Catalyst Powder}

Powder catalysts of $\mathrm{V}_{2} \mathrm{O}_{5}-\mathrm{WO}_{3} / \mathrm{TiO}_{2}$ was initially prepared by the wet impregnation method [5]. The composition $6 \mathrm{wt} \%$ $\mathrm{V}_{2} \mathrm{O}_{5}$ and $9 \mathrm{wt} \% \mathrm{WO}_{3}$ has been calculated on the basis of $\mathrm{TiO}_{2}$ First Ammonium meta-tungstate hydrate $\left[\left(\mathrm{NH}_{4}\right)_{10} \mathrm{~W}_{12} \mathrm{O}_{41}\right]$ (from Aldrich) was slowly added into the oxalic acid solution at $60-70^{\circ} \mathrm{C}$ temperature with magnetic stirring then Ammonium vanadate $\mathrm{NH}_{4} \mathrm{VO}_{3}$ (from Junsei chemical Co. Ltd.) has been added slowly to above solution with magnetic stirring in their desired compositions. $\mathrm{TiO}_{2}$ (P25) powder (Degussa Ltd.) was added slowly to above obtained green colored solution. The VWT catalyst solution was heated at $60-70{ }^{\circ} \mathrm{C}$ with magnetic stirring with agitation and then slowly evaporated until the liquid phase disappeared. The paste formation with the color change from green to blue has been observed. The catalyst paste was then treated in an air stream at $450{ }^{\circ} \mathrm{C}$ for $5 \mathrm{hr}$. The calcined VWT catalyst powder was used to prepare the coating solution of different concentration The crystallinity of the VWT catalyst powder was investigated using X-ray diffractometer (XRD). XRD patterns were captured with X-ray diffractometer D8 Advanced (Bruker) operated at $40 \mathrm{kV}$ and $200 \mathrm{~mA}$ employing $\mathrm{Cu} \mathrm{K} \alpha$ radiation.

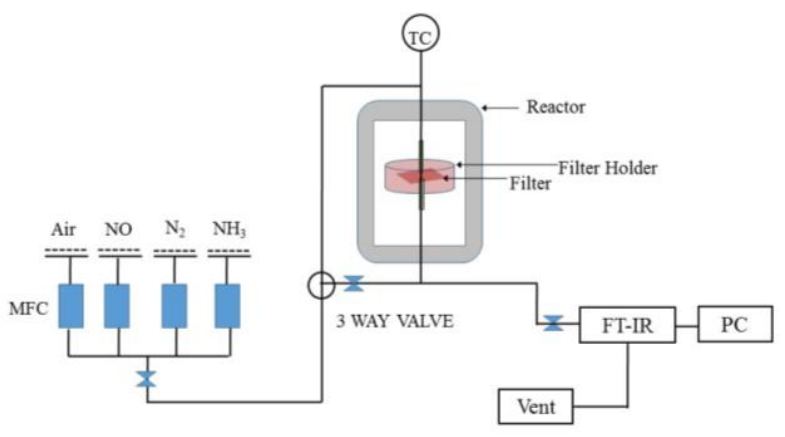

Fig. 2. Schematic representation of the reactor set up with FTIR.

\section{B. Catalyst Coating Solution Preparation}

The coating solution of the VWT catalyst has been prepared by using high energy ball milling machine with the speed of $1000 \mathrm{rpm}$ for the duration of $7 \mathrm{~min}$. to obtain a particular sized VWT catalyst particles. Catalyst particle size of the coating solution was measured during its ball milling process with the help of a particle size and shape analyzer (1090LD Shape Analyzer from SCINCO). To observe the effect of catalyst loading on the $\mathrm{NO}_{\mathrm{x}}$ performance of the catalytic sheet filter, we have prepared the different weight percentage of coating solutions like 10, 15, 20, 25, and 30 wt\% (which has been named as BM10CS, BM15CS, BM20CS, BM25CS, and BM30CS respectively, see Table I) with distilled water as a solvent. These coating solutions has further used to prepare the coated catalytic SF.

\section{Catalytic Sheet Filter Coating Method}

The ceramic sheet filter with $4 \mathrm{X} 4 \mathrm{~cm}$ dimension and 4-5 $\mathrm{mm}$ thickness has been coated with the VWT catalyst by using simple dip coating method. First the sheet filter has been cleaned with the ultrasonication process for $30 \mathrm{~min}$. at room temperature in distilled water then dried at $120{ }^{\circ} \mathrm{C}$ for $2 \mathrm{hrs}$ in an electric oven. The dried SF has been dipped into the coating solutions (prepared by ball milling) for $2 \mathrm{~min}$. and dried at $120{ }^{\circ} \mathrm{C}$ for $2 \mathrm{hrs}$ to evaporate the solvent followed by the calcination at $450{ }^{\circ} \mathrm{C}$ in an electric furnace for $5 \mathrm{hrs}$ to obtain the VWT coated SF. The specific surface area and porosity of the virgin and VWT coated SF has been measured by $\mathrm{Hg}$ porosimetry The surface morphology of the virgin and VWT coated ceramic SF has been studied by using Optical microscope (HiMax Tech. Co. Ltd., Model HT004).

\begin{tabular}{cccc}
$\begin{array}{c}\text { TABLE I: COMPOSITION OF CATALYST SUPPORTED ON SHEET FILTER USING } \\
\text { THE DIFFERENT CATALYST COATING SOLUTION CONCENTRATION }\end{array}$ \\
\hline $\begin{array}{c}\text { Catalytic } \\
\text { coating } \\
\text { solution }\end{array}$ & $\begin{array}{c}\text { Catalyst } \\
\text { concentration } \\
(\mathbf{w t} \%)\end{array}$ & $\begin{array}{c}\mathbf{V}_{\mathbf{2}} \mathbf{O}_{\mathbf{5}} \\
\mathbf{( w \mathbf { t } \% )}\end{array}$ & $\begin{array}{c}\mathbf{W O}_{\mathbf{3}} \\
\mathbf{( \mathbf { w } \% )}\end{array}$ \\
\hline BM10CS & 10 & 6.05 & 9.0 \\
BM15CS & 15 & 6.05 & 9.0 \\
BM20CS & 20 & 6.05 & 9.0 \\
BM25CS & 25 & 6.05 & 9.0 \\
BM30CS & 30 & 6.05 & 9.0 \\
\hline \hline
\end{tabular}

TABLE II: MERCURY POROSIMETRY RESULTS FOR THE VIRGIN SHEET FILTER AND BM25SF

\begin{tabular}{|c|c|c|c|}
\hline $\begin{array}{l}\text { Sr. } \\
\text { No. }\end{array}$ & Properties & $\begin{array}{l}\text { Virgin Sheet } \\
\text { Filter }\end{array}$ & BM25SF \\
\hline 1 & Total Intrusion volume (mL/g) & 0.3239 & 0.2444 \\
\hline 2 & Total pore area $\left(\mathrm{m}^{2} / \mathrm{g}\right)$ & 0.032 & 3.351 \\
\hline 3 & $\begin{array}{l}\text { Median pore diameter (volume) } \\
\text { (micron) }\end{array}$ & 54.1161 & 24.8857 \\
\hline 4 & $\begin{array}{l}\text { Median pore diameter (Area) } \\
\text { (micron) }\end{array}$ & 24.8998 & 0.0403 \\
\hline 5 & $\begin{array}{l}\text { Average pore diameter (4V/A) } \\
\text { (micron) }\end{array}$ & 40.1107 & 0.2917 \\
\hline 6 & $\begin{array}{l}\text { Bulk Density at } 0.45 \text { psia } \\
\text { (g/mL) }\end{array}$ & 1.7105 & 1.8958 \\
\hline 7 & $\begin{array}{l}\text { Apparent (skeletal) density } \\
\qquad(\mathrm{g} / \mathrm{mL})\end{array}$ & 3.8351 & 3.5326 \\
\hline 8 & Porosity (\%) & 55.4004 & 46.3355 \\
\hline
\end{tabular}

\section{Catalytic Activity Measurement}

The catalytic activity of the catalytic filters was measured in an experimental unit shown in Fig. 2, where a special reactor designed to mount the sheet type ceramic catalytic filter by keeping the commercial operation mode of the filtration in such a way that the reacting gas passes from outside into inside of the filter element. The typical reaction gas was composed of $700 \mathrm{ppm} \mathrm{NO}, 700 \mathrm{ppm} \mathrm{NH}_{3}, 7$ vol. \% $\mathrm{O}_{2}$, with balanced $\mathrm{N}_{2}$. A mass flow controller has been used to control the total gas flow rate to adjust the actual face velocity of $0.02 \mathrm{~m} / \mathrm{s}$. The catalytic activity was measured at a series of steady state temperature condition.

FT-IR spectrometer (MIDAC Prospect-IR) with a heated gas cell (Permanently Aligned 10 meter gas cell from GEMINI Scientific Instruments) and DTGS detectors were 
used to analyze simultaneously the concentrations of $\mathrm{NO}$, $\mathrm{N}_{2} \mathrm{O}, \mathrm{NO}_{2}$, and $\mathrm{NH}_{3}$. To avoid the condensation in the system all gas line tubes were heated at $120^{\circ} \mathrm{C}$. Background spectra has been recorded by using dry air. Each component's concentration was calculated by integration of the specific absorption frequencies $\left(\mathrm{cm}^{-1}\right)$ based on ethylene 938-962: NO 1873-1881, $\mathrm{N}_{2} \mathrm{O}$ 2188-2190, $\mathrm{NO}_{2}$ 1610-1614, $\mathrm{NH}_{3}$ 951-989, and $\mathrm{H}_{2} \mathrm{O} 1987-1994$. $\mathrm{N}_{\mathrm{X}}$ slip concentration (the summation of outlet concentrations of $[\mathrm{NO}]_{\text {out }}+\left[\mathrm{N}_{2} \mathrm{O}\right]_{\text {out }}+\left[\mathrm{NO}_{2}\right]_{\text {out }}+$ $\left.\left[\mathrm{NH}_{3}\right]_{\text {out }}\right)$ was used to estimate the catalytic performance which are the ultimate pollutants in the SCR unit. This simple formula, $\left([\mathrm{NO}]_{\text {in }}-[\mathrm{NO}]_{\text {out }}\right) /[\mathrm{NO}]_{\text {in }}$ was used to calculate NO. Where, $[\mathrm{X}]_{\text {in }}$ and $[\mathrm{X}]_{\text {out }}$ means the concentration of component $\mathrm{X}(\mathrm{ppm})$ in the inlet and outlet, respectively.
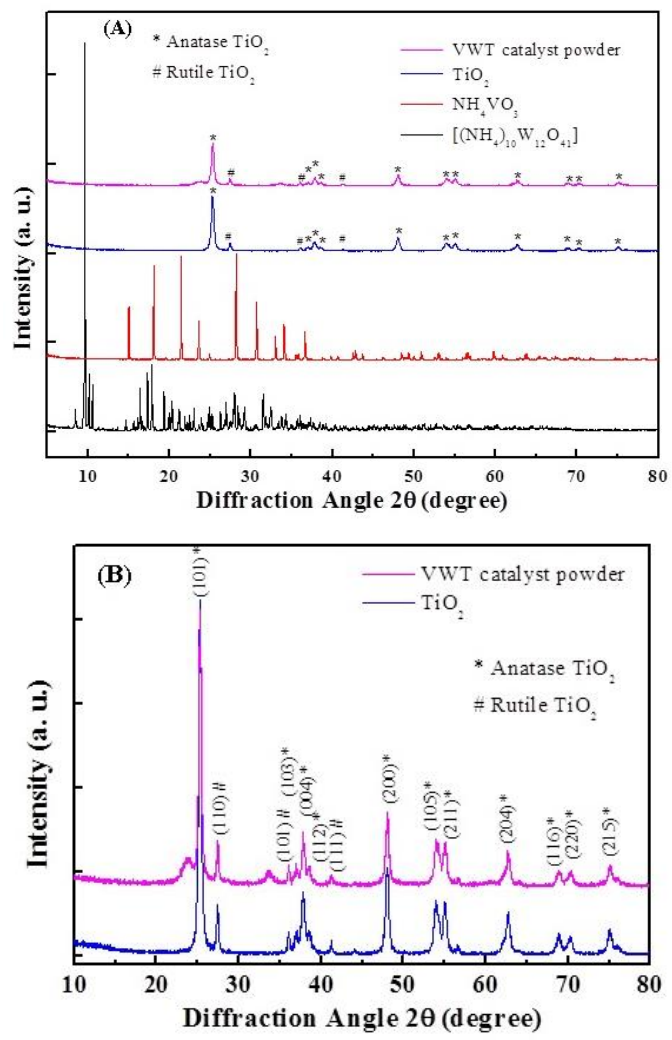

Fig. 3. XRD pattern in (A) ammonium meta-tungstate hydrate, ammonium vanadate, $\mathrm{TiO}_{2}$, and VWT catalyst powder and (B) XRD pattern in $\mathrm{TiO} 2$ and VWT for more clearity.

\section{RESULTS AND DISCUSSIONS}

Fig. 3A shows the different XRD pattern of the fresh $\mathrm{NH}_{4} \mathrm{VO}_{3},\left[\left(\mathrm{NH}_{4}\right)_{10} \mathrm{~W}_{12} \mathrm{O}_{41}, \mathrm{TiO}_{2}\right.$ and VWT catalyst powder. The diffraction peaks for $\mathrm{TiO}_{2}$ and VWT catalyst were mainly anatase phase (marked with *) (PDF-ICDD21-1272) of $\mathrm{TiO}_{2}$ with a little of rutile phase (marked with \#) (PDF-ICDD21-1276) of $\mathrm{TiO}_{2}$. To make XRD peak intensities in $\mathrm{TiO}_{2}$ and VWT much more visible a separate plots has been showed in Fig. 3B. It is worthy to note that the diffraction peaks ascribed to crystalline $\mathrm{V}_{2} \mathrm{O}_{5}$ and $\mathrm{WO}_{3}$ phase was absent in the XRD pattern of VWT catalyst powder. It suggested that $\mathrm{V}$ and $\mathrm{W}$ be well dispersed, which support and improve the catalytic activity because it was favorable for an increased number of active sites [6], [7].

Fig. 4A, B shows optical images of the virgin SF the front and back side of SF at lower magnification and Figure 5C,D shows the front and back side of the SF at higher magnification. It clearly observed that SF contains very big pores. Fig. 5A-H showed the optical images of VWT catalytic SF with $10 \mathrm{wt} \%$ (BM10SF) and $30 \mathrm{wt} \%$ (BM30SF) catalys concentration for both sides of the SF. It can be seen that the pores are largely buried by catalyst, but still some pore remained (see magnified images Fig. 5B,D,F,H) open.

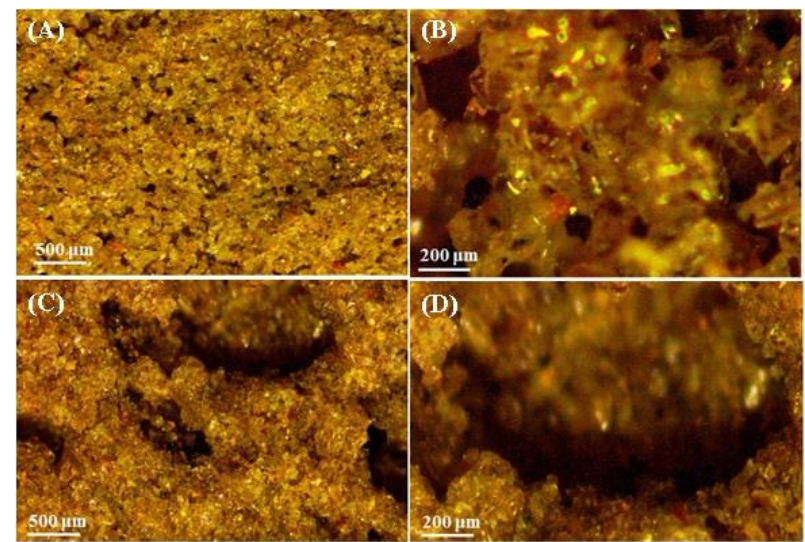

Fig. 4. Optical images of virgin sheet filter, (A, B) front side with lower and higher magnification and (C, D) of back side with low and high magnification

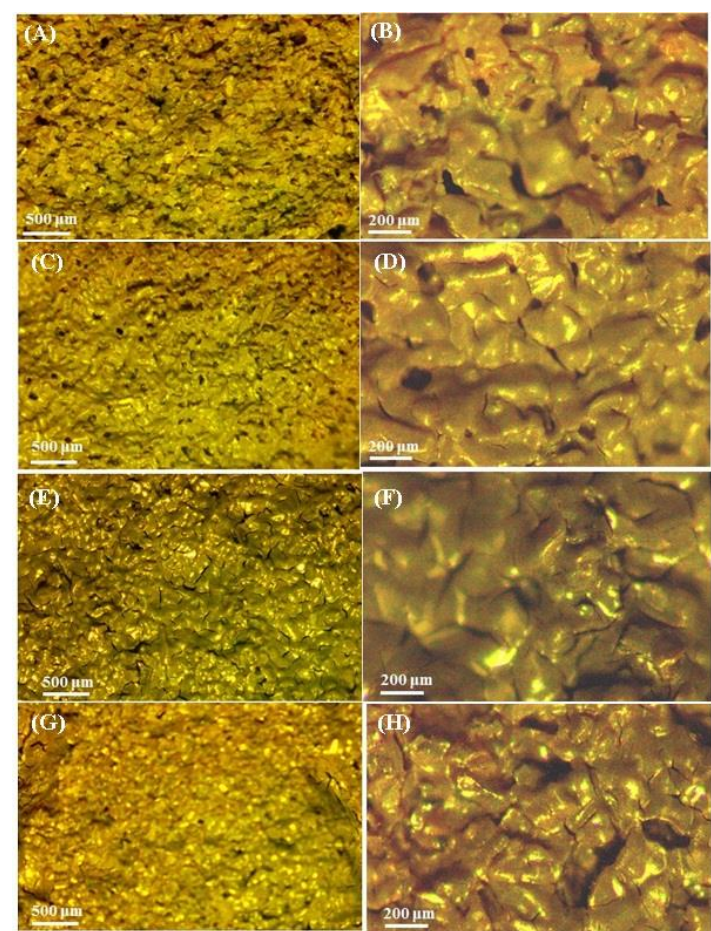

Fig. 5. Optical images of catalyst coated SF; (A, B) front side and (C, D) of back side for BM10SF and (E,F) front side and $(G, H)$ of back side for BM30SF. All left side images with lower and right side images with higher magnification.

The particle size distribution of the catalyst in the different coating solution has been showed in Fig. 6, when the concentration of the catalyst solution is low. It shows the single distribution with an average particle size of 1 micron, but as we increase the concentration more than $15 \mathrm{wt} \%$ it observed the bimodal distribution with the particle size of $\sim 1$ micron and $>2$ micron. As the amount of catalyst coating increases the pressure loss of catalyst filter increases (see Fig. 7). For BM10SF, the pressure loss was $10 \mathrm{mmH} 2 \mathrm{O}$ or less even at a filtration rate of $0.01 \mathrm{~m} / \mathrm{s}$, but increased to 40 $\mathrm{mmH} 2 \mathrm{O}$ for BM30SF. Therefore, it can be seen that when the 
concentration of the catalyst is high, the pores of the filter are filled in a large amount. However, when the concentration of catalyst was $15 \sim 25 \mathrm{wt} \%$ the pressure loss was almost similar.

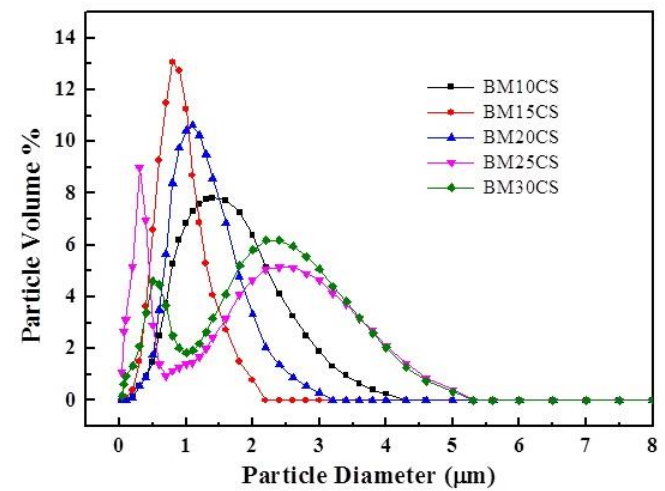

Fig. 6. Particle size distribution in BM10CS, BM15CS, BM20CS, BM25CS and BM30CS.

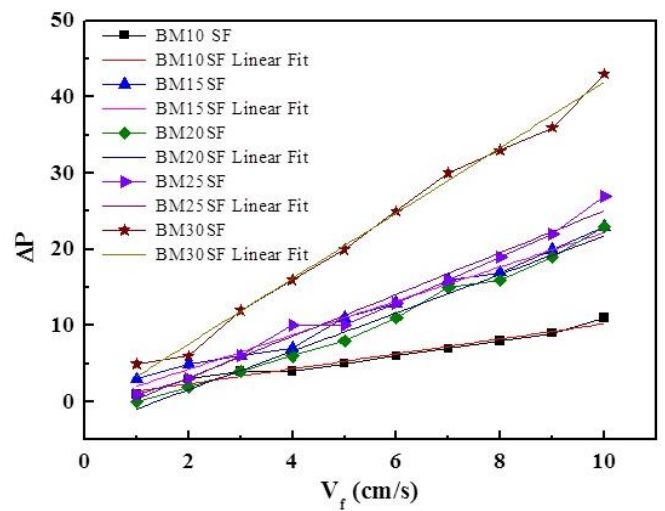

Fig. 7. Plot for pressure drop at different face velocity $\left(\mathrm{V}_{\mathrm{f}}\right)$ for sheet filter coated with 10, 15, 20, 25 and $30 \mathrm{wt} \%$ coating solution of $\mathrm{V}_{2} \mathrm{O}_{5}-\mathrm{WO}_{3} / \mathrm{TiO}_{2}$ catalyst powder with air pressure $0.1 \mathrm{kgf} / \mathrm{cm}^{2}$.

Fig. 8 shows the NO conversion rate as a performance test of the catalytic sheet filter. BM10SF showed very poor performance with a maximum conversion rate of less than $50 \%$. However, NO conversion rate increased with the increased amount of catalyst coating, and NO conversion rate was more than $90 \%$ at reaction temperature range of 260-360 ${ }^{\circ} \mathrm{C}$ for the case of BM25SF and BM30SF. In this case $\mathrm{N}_{\mathrm{x}}$ leakage is less than $50 \mathrm{ppm}$ in the reaction temperature range of $280-340{ }^{\circ} \mathrm{C}$. Fig. 9 shows the $\mathrm{N}_{2} \mathrm{O}$ formation during $\mathrm{NO}$ reduction reaction, which is less than $35 \mathrm{ppm}$ in all case of catalytic SF.

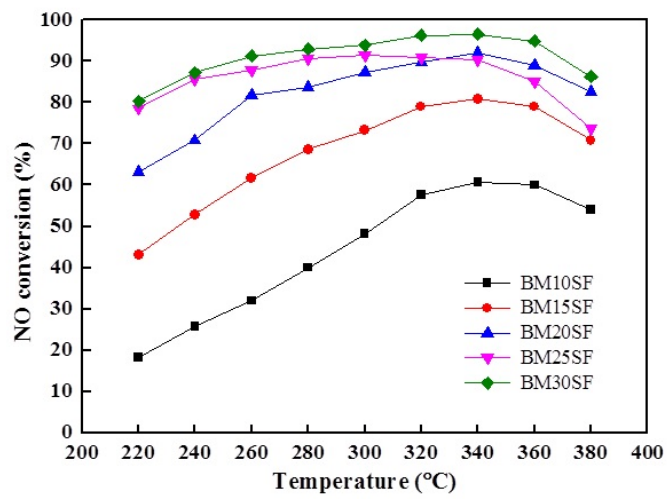

Fig. 8. Plot of NO conversion at different temperature $\left(220-380{ }^{\circ} \mathrm{C}\right)$ for BM10SF, BM15SF, BM20SF, BM25SF and BM30SF with reaction condition; $\mathrm{NO}$ and $\mathrm{NH}_{3}=700 \mathrm{ppm}, \mathrm{O}_{2}=5$ vol. \%, Face velocity $=2 \mathrm{~cm} / \mathrm{s}$.

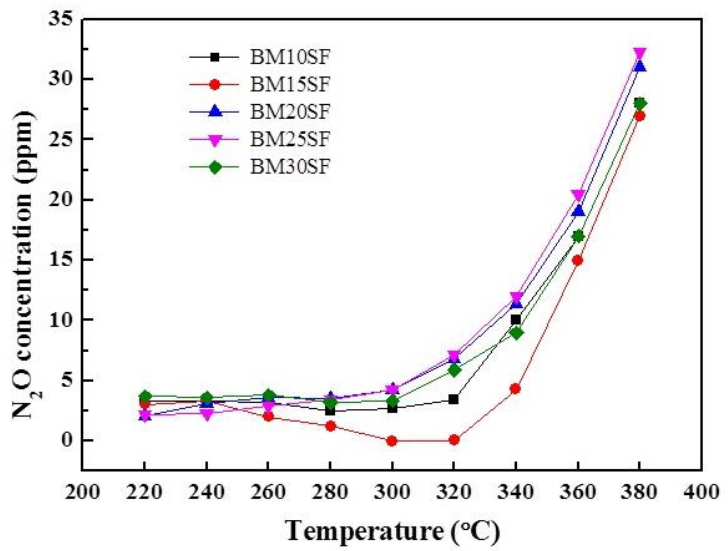

Fig. 9. Plot of $\mathrm{N}_{2} \mathrm{O}$ concentration at different temperature $\left(220-380{ }^{\circ} \mathrm{C}\right)$ for BM10SF, BM15SF, BM20SF, BM25SF and BM30SF with reaction condition; $\mathrm{NO}$ and $\mathrm{NH}_{3}=700 \mathrm{ppm}, \mathrm{O}_{2}=5$ vol. $\%$, Face velocity $=2 \mathrm{~cm} / \mathrm{s}$.
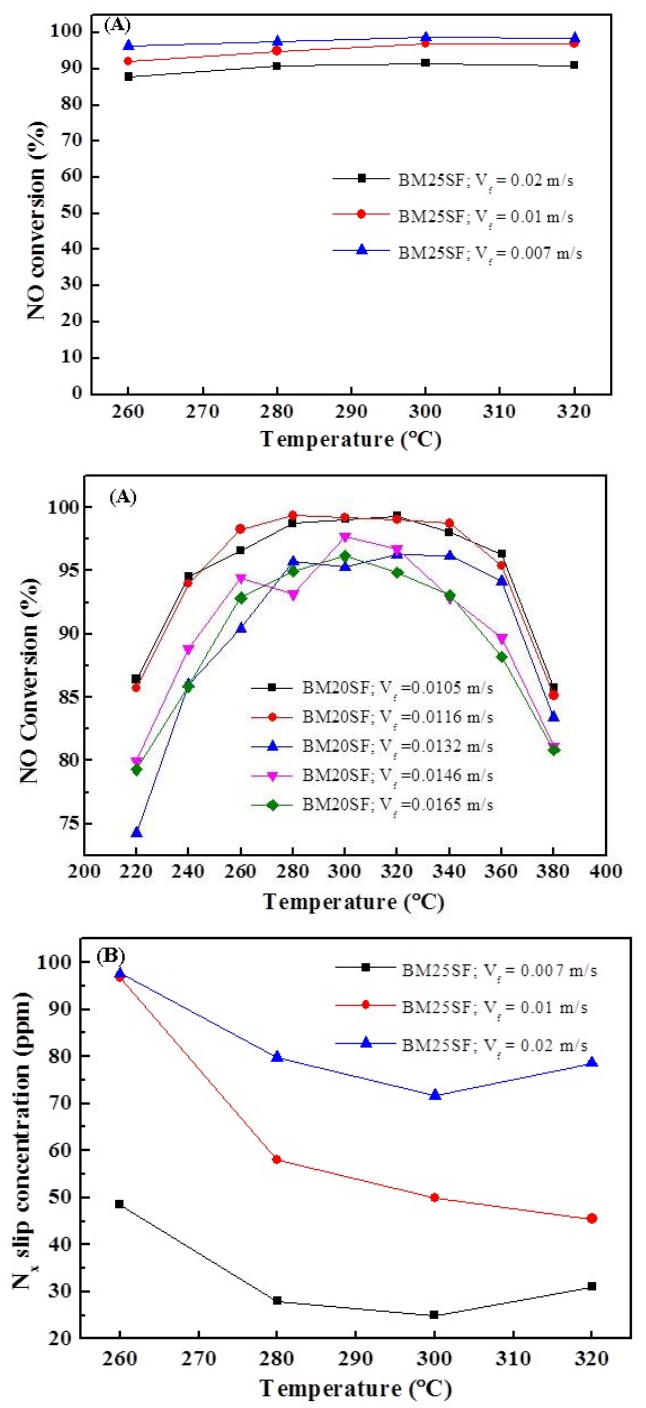

Fig. 10. (A) $\mathrm{NO}$ conversion rate and (B) $\mathrm{N}_{\mathrm{x}}$ leakage concentration with varied filtration rate for $\mathrm{NO}$ conc. $=700 \mathrm{ppm}$ for BM25SF

The filtration rate is related to the reaction residence time, and as the filtration rate is lower, the reaction contact time is increased and the reactant conversion of the catalyst is increased. It is therefore an important reaction factor to determine the amount of catalyst required to process a given reactant. Fig. 10 (A), (B) shows the activity of the BM25SF catalytic filter with varying filtration rate, i.e. reactant flow rate, without changing the composition of the reactants. When 
the filtration rate was less than $0.01 \mathrm{~m} / \mathrm{s}$, the $\mathrm{NO}$ conversion rate of $90 \%$ or more was obtained. However, at $0.02 \mathrm{~m} / \mathrm{s}$, the $\mathrm{NO}$ conversion rate was $87 \%$ and the $\mathrm{N}_{\mathrm{x}}$ leak rate was more than $70 \mathrm{ppm}$. This may be the result of the lack of the absolute amount of catalyst, but the presence of non-ideal large pores in the filter is considered to be a major cause. This is because, as shown in Fig. 11A and Fig. 11B, even in the case of BM20SF having a small catalyst coating amount, NO conversion of $97 \%$ or more and Nx leakage of less than 20 ppm can be achieved at a filtration rate of less than $0.0116 \mathrm{~m} /$ s.

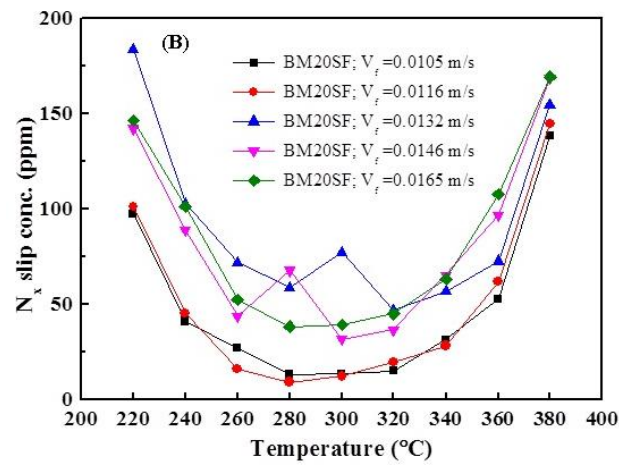

Fig. 11. (A) NO conversion rate and (B) $\mathrm{N}_{\mathrm{x}}$ leakage concentration with varied filtration rate for $\mathrm{NO}$ conc. $=700 \mathrm{ppm}$ for $\mathrm{BM} 20 \mathrm{SF}$.

It is presumed that the main reason that the sheet-like catalytic filter does not show high performance is leakage of the reaction gas through non-ideal pores existing in the filter. In order to observe how the pore size of the catalyst filter changes when the catalyst is coated, the results of Mercury porosity measurement are compared in Table II (also see the Fig. 12). The mean pore size of the crude filter without catalyst was reduced to $54 \mu \mathrm{m}$, while that of BM25SF decreased to $24 \mu \mathrm{m}$ and the average pore size decreased from $40 \mu \mathrm{m}$ to $0.34 \mu \mathrm{m}$. Therefore, it can be seen that the balls are significantly buried by coating the catalyst.

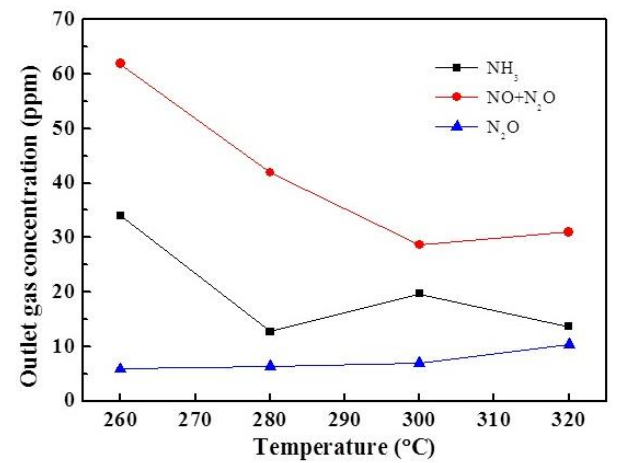

Fig. 12. Plot of outlet gas $\left(\mathrm{NH}_{3}, \mathrm{No}+\mathrm{N}_{2} \mathrm{O}\right.$ and $\left.\mathrm{NO}\right)$ concentration at different temperature $\left(260-320{ }^{\circ} \mathrm{C}\right)$ for BM25SF with reaction condition; $\mathrm{NO}$ and $\mathrm{NH}_{3}=700 \mathrm{ppm}, \mathrm{O}_{2}=5$ vol. $\%$, Face velocity $=0.01 \mathrm{~m} / \mathrm{s}$.

\section{CONCLUSION}

The XRD study reveals that $\mathrm{V}$ and $\mathrm{W}$ are well dispersed, which support and improve the catalytic activity because it was favorable for an increased number of active sites. Mercury porosimtery result proves that the pores in the virgin SF has been filled up with the VWT catalyst by dip coating method successfully, as the average pore size decreased from
$40 \mu \mathrm{m}$ in virgin SF to $0.34 \mu \mathrm{m}$ in BM25SF. Microstructural study also supports this. Improved NO conversion has been achieved with the increase in the concentration of catalytic coating solution. NO conversion rate was more than $90 \%$ at reaction temperature range of $260-360{ }^{\circ} \mathrm{C}$ for the case of BM25SF and BM30SF with $\mathrm{N}_{2} \mathrm{O}$ formation less than $35 \mathrm{ppm}$. But the pressure loss for BM30SF is quite more compare to others, the plausible reason is the failure of absolute catalyst loading amount; however the non-ideal large pores present in the SF is the main cause for this. Because in the case of BM20SF even with small catalyst coating amount compare to BM25SF and BM30SSF, NO conversion of more than $97 \%$ and $\mathrm{Nx}$ leakage less than $20 \mathrm{ppm}$ achieved at filtration rate of $0.116 \mathrm{~m} / \mathrm{s}$. BM25SF shows the more than $90 \% \mathrm{NO}$ conversion at $0.01 \mathrm{~m} / \mathrm{s}$ filtration rate and $87 \%$ for $0.02 \mathrm{~m} / \mathrm{s}$ filtration rate. Modification of the $\mathrm{TiO}_{2}$ with polymer to prepare the catalyst and to develop a good catalytic sheet filter has a wide scope in the future.

\section{REFERENCES}

[1] P. Forzatti, "Present status and perspectives in de-NOx SCR catalyst," Applied CatalysisA: General, vol. 222, pp. 221-236, December 2001

[2] G. Busca, M. A. Larrubia, L. Arrighi, and G. Ramis, "Catalytic abatement of NOx: Chemical and mechanistic aspects," Catal. Today, vol. 107, pp. 139-148, August 2005

[3] P. Forazatti, I. Nova, E. Tronconi, A. Kustov, and J. R. R. Thogersen, "Effect of operating variableson the enhanced SCR reaction over a commercial V2O5-WO3/TiO2 catalyst for stationary applications," Catal. Today, vol. 184, pp. 153-159, April 2012

[4] G. Saracco and L. Montanaro, "Catalytic ceramic filter for flue gas cleaning.1. Preperation and characterization," Ind. Eng. Chem. Res., vol. 34, pp. 1471-1479, April 1995

[5] J. H. Kim, J. H. Choi, and A. D. Phule, "Development of high performance catalytic filter of $\mathrm{V}_{2} \mathrm{O}_{5}-\mathrm{WO}_{3} / \mathrm{TiO}_{2}$ supported-SiC for NOx reduction," Powder Technology, vol. 327, pp. 282-290, January 2018

[6] L. Baraket, A. Ghorbel, and P. Grange, "Selective catalytic reduction of NO by ammonia on V2O5-SO42-/TiO2 catalysts prepared by the sol-gel method," Appl. Catal. B: Environ., vol. 72, pp. 37-43, March 2007

[7] G. Qi and R. T. Yang, "Low-temperature selective catalytic reduction of $\mathrm{NO}$ with $\mathrm{NH}_{3}$ over iron and manganese oxides supported on titania," Appl. Catal. B: Environ., vol. 44, pp. 217-225, August 2003.

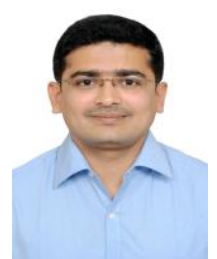

Phule Ajit Dattatray was born on May 7, 1985 at Malinagar, Maharashtra, India. He has graduated as a Ph.D. from Materials Science Centre, Indian Institute of Technology Kharagpur, West Bengal India in 2014 (2008-2014). During his Ph.D., he worked on synthesis and characterization different Nanomaterial, nanofluids and polymer nanocomposites. In 2015 , he joined as an institute postdoc fellow in chemical engineering Department, Indian Institute of Technology Kanpur, Uttar Pradesh, India to work on Inorganic organic hybrid Solar cell device fabrication. At present, he is a Senior Researcher (Postdoc Fellow) at Chemical Engineering Department, Gyeongsang National University, Jinju, South Korea since Dec. 2016. His current research topic is Development of Ceramic Catalytic Sheet filter for the simultaneous reduction of NOx and particulates for the application in diesel engines. During his research career, he has authored and co-authored several scientific publications (Elsevier, ASP, RSC, AIP, Taylor and Francis etc.) in International Journals and Conferences. He is also reviewer and Editor for the International Journals.

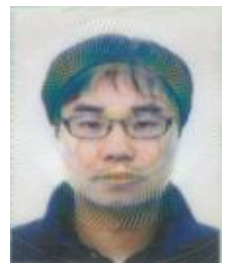

Kim Jim Hyong was born on September 28, 1977 at Gyung-nam, South Korea. He was graduated as a Ph.D. from Chemical Engineering Department, Gyeongsang National University, South Korea in 2012.(2007-2012).During his Ph. D., he worked on dust removal and dust collection characteristics, NOx removal and Gas removal characteristics. In 2012, he joined as an institute post-doc. fellow in Chemical 
Engineering Department, Gyeongsang National University, South Korea. (2012-2014).At present, he is a CTO (chief technology officer) at KYUNGSUNG INDUSTRY CO., LTD. Busan, South Korea since 2014. His current research topic is Development of Ceramic Catalytic Sheet filter for the simultaneous reduction of NOx and particulates for the application in diesel generator engines.During his research career, he was authored and co-authored several scientific publications in International Journals and Conferences.

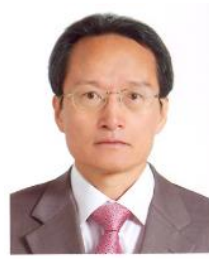

Joo Hong Choi was born on March 221955 at Gyung-nam, South Korea. He has a $\mathrm{PhD}$ degree in chemical reaction and catalyst from Seoul National University in 1988. He is a professor in the Department of Chemical Engineering for Gyeongsang National University from 1989 and has more than 20 years experiences in the fields of advanced ceramic filter. Choi has worked most of his research times for development of advanced ceramic filter unit for removal of particulates at high temperature and high pressure like Integrated Gasification Combined Cycle (IGCC) and Pressurized Fluidized Bed Combustion (PFBC) as well as the development of catalytic filter. Catalytic filter is his focused research field to develop the bi-functional advanced ceramic filter to treat the particulate and nitrogen oxides simultaneously. 